\title{
Computer Simulations in Mechanics at the Secondary School
}

\author{
Stanislav HOLEC, Miriam SPODNIAKOVÁ PFEFFEROVÁ, \\ Jana RAGANOVÁ \\ Department of Physics, Matej Bel University Banská Bystrica \\ Tajovského 40, 97401 Banská Bystrica, Slovakia \\ e-mail:holec@fpv.umb.sk,pfeffer@fpv.umb.sk,raganova@fpv.umb.sk
}

Received: August 2004

\begin{abstract}
Computer simulations seem to be one of the most effective ways to use computers in physics education. They encourage students to carry out the processes used in physics research: to question, predict, hypothesise, observe, interpret results etc. Their effective use requires an availability of appropriate teaching resources fitting secondary schools curricula.

This paper presents a set of computer simulations that cover the curriculum area of Mechanics and are designed to fit directly to curricula and textbooks used at Slovak grammar schools. All simulations are accompanied by brief instructions for teachers, including suggestions for learning activities and problem tasks for students. Some of them are designed as virtual laboratories.

The developed simulations were tested with a group of secondary school students and evaluated also by groups of future and practising physics teachers. The paper presents and discusses findings and conclusions from the both runs of the testing.
\end{abstract}

Key words: modelling, computer simulations, mechanics, testing.

\section{Introduction}

Integration of information and communication technologies (ICT) into schools and the whole society of the Slovak Republic is lagging in comparison with well-developed countries of European union. Slovak society that had overcome a significant economical transformation in the last decade started also with transformation of its technological structure. ICT should be a natural motor of this transformation. One of the government's goals on the move towards information society is to equip all primary and secondary schools (about 3300 within the country) with multimedia PC labs connected to Internet before the end of 2004. This should be accompanied by the necessary curriculum development for all subjects and teacher training in using ICT.

In spite of the rather slow progress in equipping schools with modern ICT, it has been strongly felt at least for the last 20 years that it is necessary to incorporate the use of ICT into science subjects, which are taught separately in Slovakia. The most important reason for this effort is a strong link between science and computer technology. Much of today's research in physics, chemistry and biology is computer managed and there is a 
general agreement that methods used in school science should reflect this trend. Students should be allowed to experience science in computer-based laboratory exercises as it is done in science research. These ideas resulted in many curriculum development activities especially at universities, which train future teachers.

In physics education, these goals officially became a part of school policy in 1997, when new educational aims were incorporated into physics curricula for Slovak grammar schools (age 15-19). The words "information technology" occurred for the first time in the curricula in connection with modelling activities. According to this newly formulated aim "students should be able to model basic physical phenomena and processes with an effective use of modern information technologies“(Učebné osnovy, 1997). This aim has connected two trends of today's physics education: strengthening of the role of IT and didactical transformation of modern research methods into school learning.

Fulfilling such an aim is possible only if some basic conditions are satisfied. These include first of all the needed technology in the classroom, the well-trained teacher and appropriate teaching resources.

In this paper we focus on the latter. After a short discussion of computer modelling the examples of created computer simulations are introduced together with brief notes for their use in the classroom. The final part of the paper summarizes results of testing within three different groups of users.

\section{Method of Computer Simulations}

Besides the real experiment supported by the computer, modelling methods represent one of the most progressive computer-based teaching / learning methods in physics education. They supplement real labs and are even more appropriate in some cases (dangerous or costly experiments).

In our survey we concentrate only on one of the computer modelling methods method of computer simulations. Computer simulations are programs that allow the user to interact with a computer representation of scientific model of natural or physical world. These programs can be used as demonstrations by teachers, or they can be used directly by students to explore various systems and manipulate variables.

Students can observe visually the physical process running on the computer screen in the "real environment". The opportunity to change parameters of the interacting bodies, characteristics of the environment, character and quantity of interactions between the bodies, provide a possibility to explore the process in different conditions. A great advantage of such simulations is their ability to model also the conditions that cannot be reached in the real laboratory: the environment without air resistance, without friction, without gravitation etc.

Through their power to animate, simulations can communicate dynamic information more accurately than a diagram and can help students to visualize various phenomena. They enable students to see things that are normally too fast, too slow or hidden. Students are offered to watch simultaneously a graph being plotted as they are exploring the process. The values of the quantities can be usually read and used in further calculations. 
Due to the described characteristics the method of computer simulations represents an important learning method: It can help to develop students' inductive and deductive thinking as well as their capability to solve problems, formulate and test hypotheses, to investigate relationships between natural phenomena and processes.

There are several modelling tools available on Slovak market but most of them use English language to communicate with the user. Because it is necessary to use resources in students' mother tongue at schools we decided to develop modelling activities for Slovak students in Interactive physics program, that can be easily localised into Slovak.

Simulations created in Interactive physics provide learner-centred environments that allow students to investigate various systems and phenomena. The program is suitable mainly for modelling of dynamical simulations of mechanical processes. The model can be easily set up by inserting objects from the tool bar. The values of quantities can be changed directly in the simulation with the help of available tools. The managing of models is very easy - it is done by START and RESET buttons. The STOP button allows stopping the explored process at any moment.

In the next part we introduce a couple of simulations from the developed set covering the curriculum area of Mechanics, which is taught in the first year of Slovak grammar schools. We choose topics of motions in gravitational field and the law of conservation of linear momentum.

\section{Examples of Computer Simulations}

The developed computer simulations can be used as demonstration tools or as problem tasks for students. It is a role of the teacher to decide for the most appropriate way of their application in the concrete learning setting.

Each of the simulations is accompanied with short instructions for the teacher. These include:

- description of simulation;

- application of simulation - a recommendation of the possible integrating of the simulation into the teaching process;

- tasks for students.

The first example from the developed set is introduced together with the complete instructions, other simulations are only briefly characterised.

\subsection{A Projectile Motion}

\section{Description of Simulation}

An object is thrown upward with initial velocity $\nu_{0}\left(\nu_{0}=8.5 \mathrm{~m} \mathrm{~s}^{-1}\right)$; the user can change the angle of inclination (Fig. 1). A trajectory of the moving object is recorded. The button of air resistance enables exploration of the projectile movement in an ideal (without air resistance) or in a real environment. If the real environment is set up, the trajectory of the moving object is not a parabola, but so-called ballistic curve. 


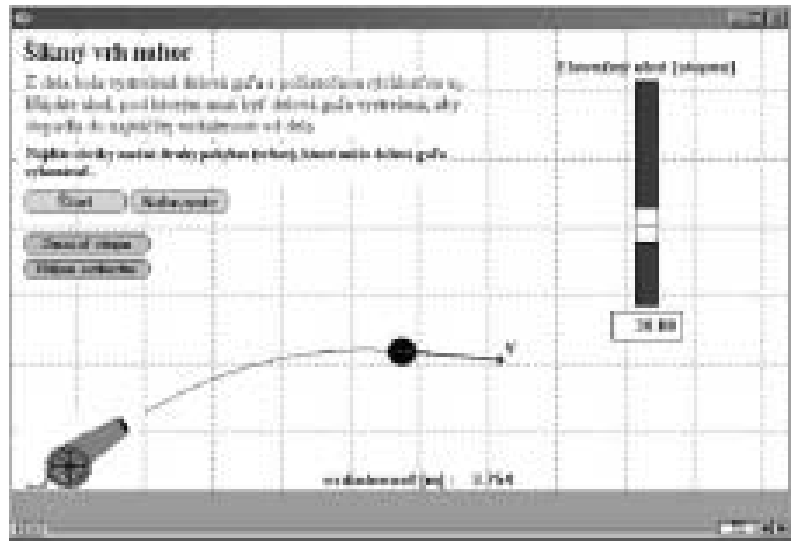

Fig. 1. A projectile motion.

\section{Application of Simulation}

The simulation offers investigation of basic features of the projectile motion. Students can analyse the parabolic trajectories of the moving objects at various angles of inclination in both the ideal and real environments. After the initial observation students can solve a series of problem tasks.

\section{Tasks for Student}

- Compare the trajectories of the projectile thrown upward in the ideal and real environments. Which phenomenon causes their difference?

- Try to find an angle where the range of the projectile thrown upward is maximal in the ideal as well as in real conditions. Compare the values so obtained.

\subsection{The Circular and the Escape Speed}

The simulation demonstrates motion in space (Fig. 2). An object (the smaller circle), which is $3 \mathrm{~km}$ above the Earth's surface (the bigger circle), is moving around the Earth. In the beginning the user can set an initial speed of the object using a speed button. If the object's initial speed is the circular speed, it has got a circular orbit. If the object's initial speed is bigger, the orbit is an ellipse. The object leaves the gravitational field of the Earth, if its initial speed is equal to or bigger than the escape speed. In each of these cases students can observe a graph of speed vs. time.

\subsection{The Motion of the Planet and the Satellite}

The simulation (Fig. 3) introduces a process of gravitational interaction between the planet and the satellite. Speed buttons enable changing a speed of the moving planet (the bigger object) and the satellite (the smaller object). A graph of speed vs. time presents how the gravitational field of the planet influences the satellite's motion. The simulation 


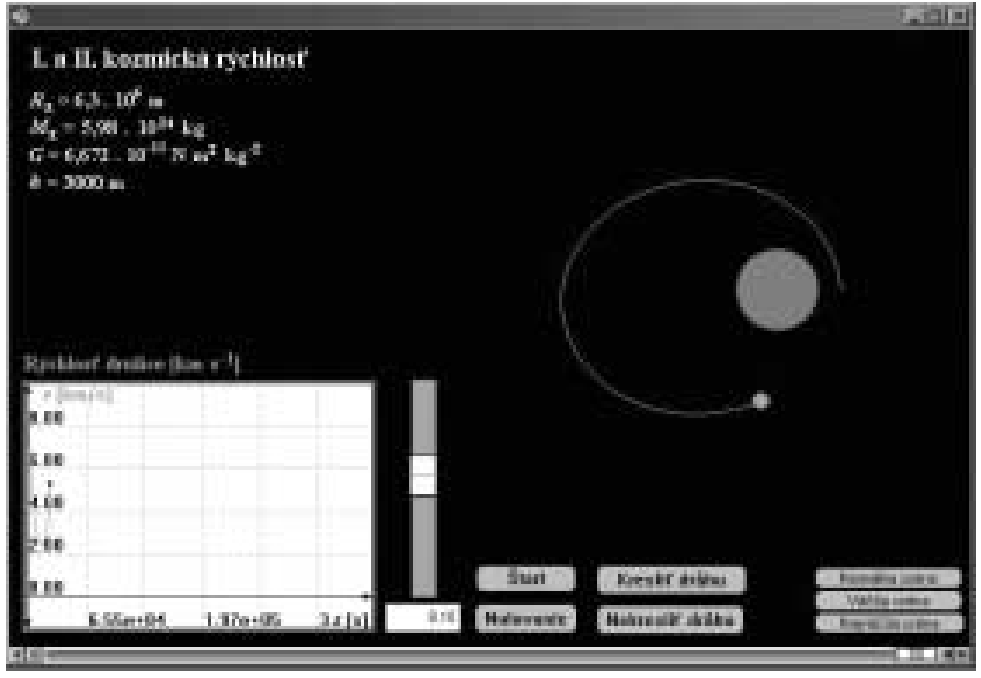

Fig. 2. The circular and the escape speed.

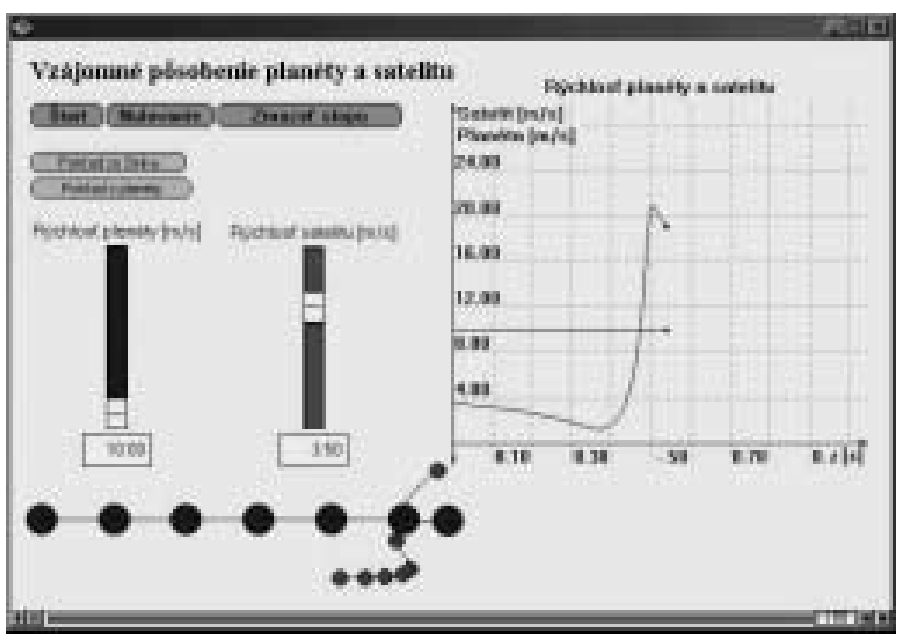

Fig. 3. The motion of the planet and the satellite.

shows that the planet's gravitational field causes a change of a satellite's trajectory and speed.

\subsection{The Conservation of Linear Momentum}

There are two moving objects connected by an elastic thread in this simulation (Fig. 4). Masses of the objects can be changed using mass buttons. The elastic thread causes the same impulses (but with different directions) to affect to the objects. After starting the simulation we can observe a graph of the linear momentum vs. time. The numeric values 


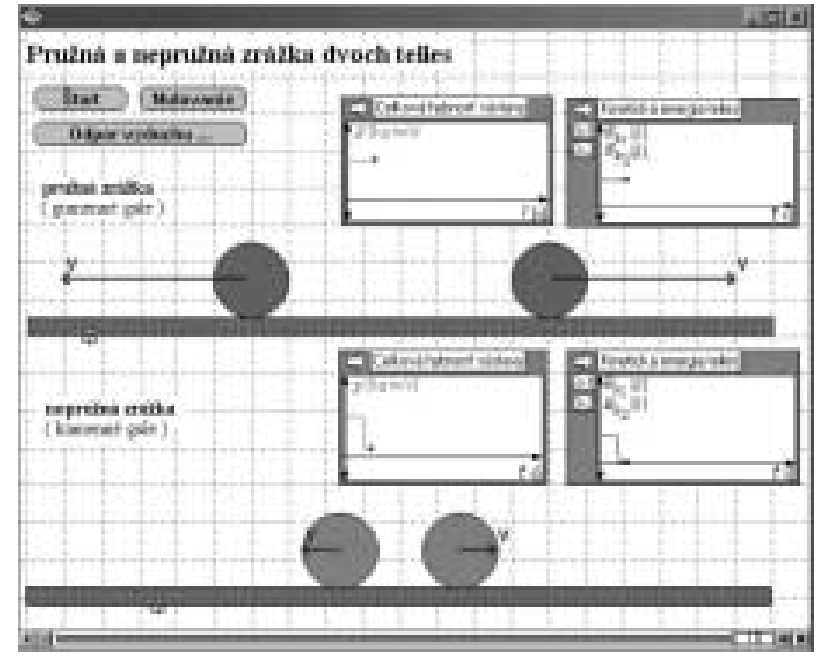

Fig. 4. The conservation of linear momentum.

of linear momentum of the both moving objects are available, too. Buttons PREVIOUS STEP and NEXT STEP enable to return the objects to the moment of a collision and to find out its coordinates. The simulation can be used as a virtual laboratory with a task for students to prove the conservation of linear momentum.

\section{Survey Results}

The developed simulations were tested with secondary school students of two classes (63 altogether) in school year 2003/2004. Simulations were used at an experimental class (EC) by 15 and 16 years old students ( $1^{\text {st }}$ class) to become familiar with basic features of physical processes of mechanics. After finishing of this part of physics curricula students did a test by which their understanding of introduced processes was checked. The second group of students (from the same school) who didn't use simulations during physics lessons (control class - CC) did the same test at the same time. Results of the both tests are compared on a graph below (Fig. 5).

The $\mathrm{x}$-axis of the graph plots the successfulness of students in \%. It is divided into five equal intervals which limiting values are: $1^{\text {st }}(22.81-38.25 \%), 2^{\text {nd }}(38.26-53.69 \%), 3^{\text {rd }}$ $(53.70-69.13 \%), 4^{\text {th }}(69.14-84.56 \%)$ and $5^{\text {th }}(84.57-100.00 \%)$. Y-axis shows a frequency of an appearance in individual intervals, it means how many students attain a particular level of successfulness in the test (in \%).

Following the graph we can deduce that students of the experimental class were more successful than students of the control class. Better results of students of EC support a statement that an integration of computer simulations into school physics influences a students' level of physics knowledge positively. 


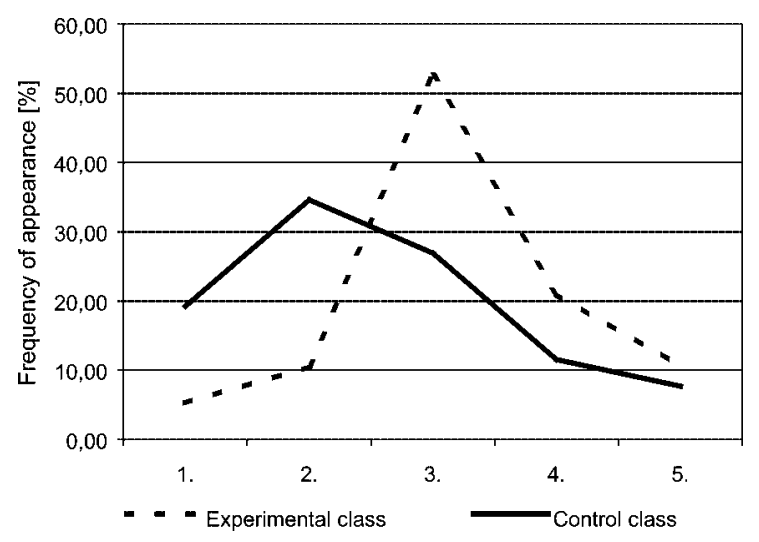

Fig. 5. Comparison of test results of the experimental and control classes.

Besides the testing of students' understanding of mechanical processes students were asked to fulfil a questionnaire focused on some other aspects of integration of computer simulations into school physics - students' motivation and interests to learn physics.

The results of the questionnaire show that only a few students from both classes like physics and regard this subject as interesting one. A lot of students (every fifth of them) expressed that they hated physics and this subject was very difficult and incomprehensible for them. On the other hand, $98 \%$ of students like working with the computer, although they use it only in informatics course. All of these students proved that physics lessons with the use of the computer simulations would be very interesting for them. They evaluated positively first of all a possibility of visualisation of the explored processes, their graphical presentation as well as an offer to modify experimental conditions.

The second phase of the survey aimed at teachers and their attitudes to the method of computer simulations. The first group of respondents was a group of future physics teachers. The various approaches to ICT integration into school physics form a part of their training and they are skilled very well in the use of modern ICT. The whole group evaluated the introduced tested simulations very well and recommended their use in the classroom.

The second group of potential users were practising teachers who were interviewed during a workshop focused on computer-supported physics teaching. Surprisingly, although all of the teachers ( 28 altogether) were experienced and their participation on the workshop proved their interest in integration of ICT into their practice, the workshop meant their first opportunity to work with computer simulations. A friendly environment was set up to overcome an initial fear of the teachers, who finally managed to "play" with simulations without any problems. Their responses in the interview proved their interest in the method, although one of the most important reasons for them was that it required only a small initial investment of time and costs comparing with the method of real experiments supported by computers. The greatest obstacle to integration the method into the classroom is for them an "organisational difficulty". Even when a school is equipped with computers, these are not placed in physics labs and computer rooms are usually not 
available for the physics teacher. And according to the teachers, it needs too much effort to change this status quo.

\section{Conclusions}

The realised survey proves that computer simulations represent a method that could first of all significantly enhance student motivation and interests to learn physics. The gained experience with all the groups of possible users let us believe that teaching supported with computer simulations provides students with efficient and effective opportunities to learn both science's products and processes which can be useful for students also in other areas or in their future professions. With the hope that more students will be everyday exposed to computer technology in Slovak schools the further developments have been done within the international partnership in Leonardo da Vinci EU-funded project Computerised laboratory in science and technology teaching.

\section{References}

Computerised Laboratory in Science and Technology Teaching (2004). http://e-prolab.com/comlab

Interactive Physics II. User guide (1996). [s.1., s.n.]

Riche, B., and S. Dawe (2002). Using Microcomputer Based Labs and Simulations in High School Science. http://www.bishops.ntc.nf.ca/rriche/ed6620/microcomputer.html

Učebné osnovy gymnázia - štvorročné štúdium. Fyzika, povinný učebný predmet (in Slovak, Curriculum for the grammar school - four-year study programme. Physics, a compulsory study subject) (1997). Ministry of Education of the Slovak Republic. 
S. Holec is a dean of the Faculty of Natural Sciences, Matej Bel University Banska Bystrica. He has more than 15 years of experience teaching physics at future physics teachers training programme, where he has specialized at optics. He has published widely; his research work concentrates on didactics of physics and science, especially on real and model physics and science school experiments aided by the computer. $\mathrm{He}$ was involved in several curriculum and resource development projects. From 1995 to 1998 he coordinated the Joint European Project Tempus Science Teacher Training 2000 focused on science teacher training.

M. Spodniakova Pfefferova is a PhD student at the Faculty of Natural Sciences, Matej Bel University Banska Bystrica. Her research work is focused on experiments at school physics supported with ICT.

J. Raganova works as a senior lecturer at the Physics Department at the Faculty of Natural Sciences. Her research interests include problems of theory of physics education, new approaches to school physics based on pupils' investigative activities, ICT tools and integration approaches to science subjects teaching.

All the three authors collaborated at the ComLab-SciTech project (2000-2004) and are currently involved at curriculum development project Real and Virtual Laboratories in Education. 


\title{
Kompiuterinis modeliavimas vidurinès mokyklos mechanikos kurse
}

\author{
Stanislav HOLEC, Miriam SPODNIAKOVÁ PFEFFEROVÁ, Jana RAGANOVÁ
}

Ivairių metodu modeliavimas panaudojant kompiuterius tampa vienu efektyviausiu fizikos mokymo būdu. Šis metodas leidžia besimokančiajam geriau isisavinti žinias, reikalingas fizikiniams tyrimams atlikti, skatina kelti hipotezes ir klausimus, numatyti rezultatus, ugdo pastabuma bei gebejjimą analizuoti. Tačiau norint užtikrinti šio metodo efektyvumą reikia, kad pasitelkiami mokymo ištekliai atitiktų vidurinių mokyklų mokymo programą.

Straipsnyje supažindinama su parengtais kompiuterinio modeliavimo taikymais dèstant mechanikos kursą Slovakijos vidurinėse mokyklose. Aptariami jụ pritaikymai šios šalies mokymo programai ir vadovèliams. Prie kiekvieno kompiuterinio modelio pateikiama ir trumpa instrukcija mokytojui, kurioje pasiūlomos tam tikros mokymo gairès bei konkrečios užduotys. Kai kurios tokiu programų sukurtos pagal virtualių laboratoriju pavyzdi. Sukurti kompiuteriniai modeliai mechanikos kursui buvo išbandyti su grupe vidurinès mokyklos moksleiviu, ju nauda aptarta su būsimais ir esamais fizikos mokytojais. Straipsnyje supažindinama su šio testavimo duomenimis bei išvadomis. 